\title{
De forskellige tilgange til religionsundervisningen
}

Af BJøRG Bogisch, mag. art. i religionsvidenskab, lektor ved Lareruddannelsen Carlsberg, Københavns Professionshøjskole

Nærværende indlæg er ikke et forsøg på at skabe en facitliste over, hvilke fagdidaktiske tilgange man kan finde i religionsundervisning generelt, og hvilke fagdidaktiske valgmuligheder man følgelig må have. Ambitionen er derimod at bidrage med en overskuelig opstilling over (nogle af) de fagdidaktiske tilgange, som har præget den danske religionsundervisning i grundskolen fra faget kristendomskundskabs indførelse i 1975. Det danske religionsfag har sin egen tradition, men udviklingen af faget er naturligvis ikke foregået isoleret fra de religionsdidaktiske traditioner i vores nabolande, hvorfor denne opstilling forhåbentlig kan være anvendelig at tale ud fra - og måske udbygge og ombygge - som religionsdidaktiker i de øvrige skandinaviske lande.

Nedenstående opstilling er i høj grad inspireret af og bygger på bogen Religionsdidaktik (2006) redigeret af Mette Buchardt. Som Buchardt fremhæver i sit indledende kapitel skal de fagdidaktiske tilgange ikke forstås som afgrænsede enheder, som læreren kan vælge sig én af. Der er tale om traditioner, som læreren kan lade sig inspirere af og udfordre. Bogen anvender Karstens Schnaks kriterier for sammenlignende fagdidaktik, som rejser følgende spørgsmål (Buchardt 2006: 31):

- Hvilken fagkritik og selvforståelse?

- Hvilket menneskesyn, samfundssyn, dannelsesbegreb?

- Hvilken videnskabsteoretisk position, erkendelsesteoretisk position, hvilket læringsbegreb?

- Hvilke implikationer for pædagogiske kategorier?

Jeg har igennem årene sammen med mine studerende læst Buchardts fagdidaktik (også i en revideret udgave fra 2016) samt andre fagdidaktiktikker og vejledninger i faget med disse spørgsmål i baghovedet. Med tiden har det givet mening for mig at opstille følgende spørgsmål til de enkelte fagdidaktiske tilgange:

- Hvilket dannelsesmål er det dominerende i tilgangen?

- Hvilke metoder anvendes typisk?

- Hvilket indhold står centralt?

- Hvilket bagvedliggende religionssyn ligger implicit i tilgangen?

- Hvilket menneskesyn bygger tilgangen på?

- Hvilken videnskabelige tradition trækker tilgangen på? 
Ud fra disse spørgsmål, læsning af fagdidaktikker og feedback fra kolleger (ikke mindst Jeppe Langkjær) ser mit bud på en skematisk oversigt over de religionsdidaktiske tilgange således ud:

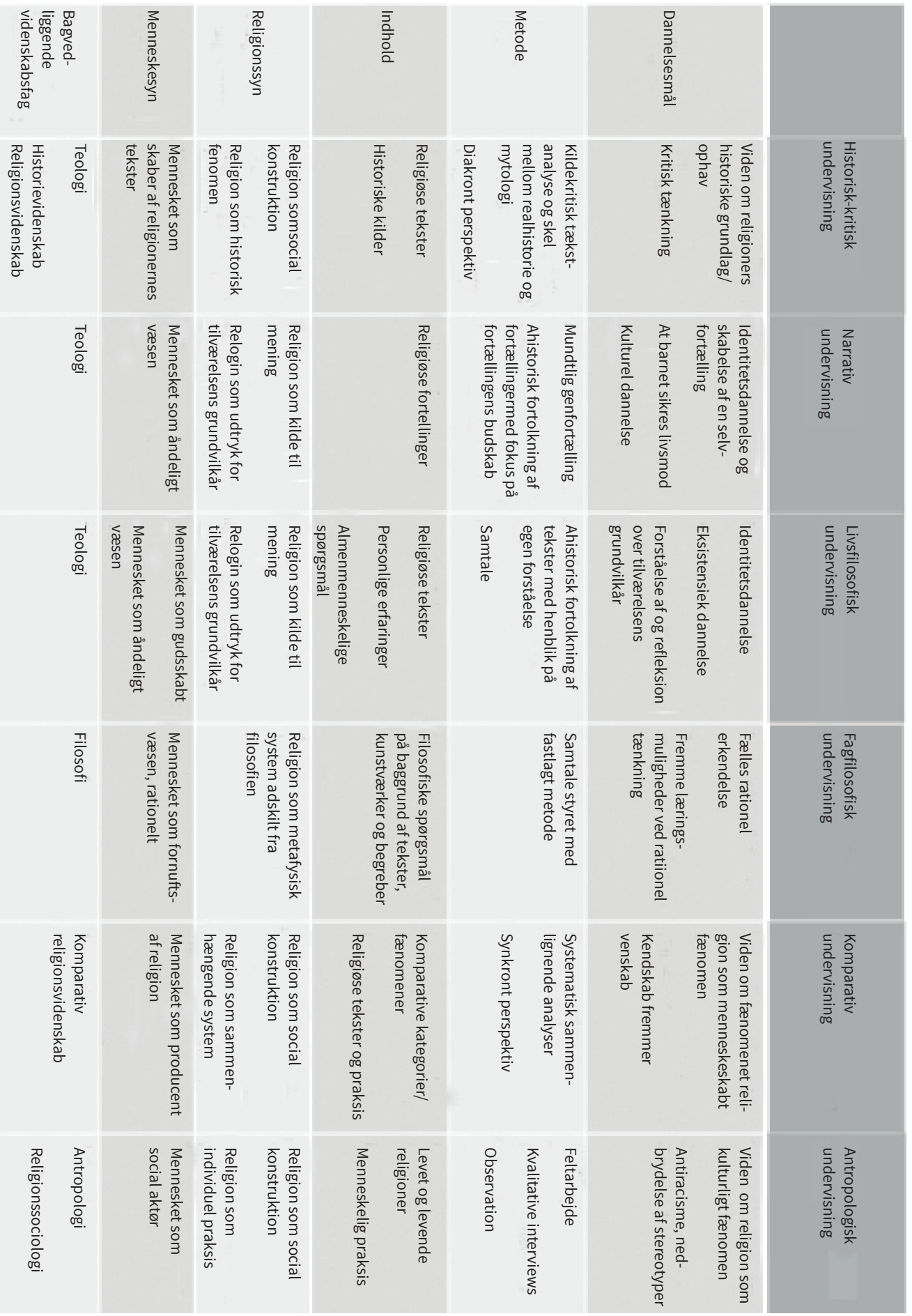


Man kunne have valgt andre tilgange end de seks her opstillede. Fx beskriver tidligere faghæfter den æstetiske tilgang. Denne har jeg fravalgt, da jeg anser æstetiske læreprocesser, som noget der kan foregå i kombination med de her opstillede tilgange. Det samme kunne man sige om den narrative tilgang. Er det overhovedet en tilgang i sig selv, eller handler narrativ undervisning om at anvende fortællinger i undervisningen. Når jeg beskriver den narrative tilgang her, så er det i en version, hvor den levende fortælling står i centrum, og hvor dannelsesmålet er identitetsdannelse og skabelse af en selvfortælling. I den narrative undervisning - $\mathrm{i}$ denne version - ses fortællingen som en kilde til mening, et afsæt for at tage samtaler om menneskets grundvilkår.

Heroverfor står den historisk-kritiske tilgang, hvor fortællingen ses som en skriftlig kilde, og metoden vil som udgangspunkt være kildekritisk tekstanalyse. Den historisk-kritiske tilgang til undervisningen var dominerende i den danske grundskoles religionsfag umiddelbart efter faget blev til et kundskabsfag i 1975. Tilgangen beskrives i fagets styringselementer stadig som central i faget, hvilket også er tilfældet for den narrative tilgang, der blev skrevet tydeligt ind i faget i 1989.

Den livsfilosofiske tilgang er beslægtet med den narrative tilgang, og man kan sagtens finde eksempler, hvor de to tilgange vil være overlappende. Livsfilosofien blev skrevet ind i det danske fag i 1995, og den blev siden kritiseret blandt andet for at bygge på et skabelsesteologisk menneskesyn (Böwadt 2007). Siden er tilgangen blevet livligt diskuteret og beskrivelser justeret. Det er ligeledes blevet diskuteret, hvorvidt man også skal tale om en eksistentiel tilgang, samt om denne er (delvist) overlappende med den livsfilosofiske. I undervisningsmaterialer vil man ofte se, at de to tilgange kan være overlappende, mens flere fagdidaktikere anbefaler at holde dem ude fra hinanden som to selvstændige kategorier, der bygger på forskellige epistemologiske paradigmer. Denne diskussion bliver for omfattende at gå ind i her, men man kan finde argumenter for at adskille de to tilgange hos Böwadt (i: Buchardt 2006: 123/Buchardt 2016: 173ff) og Jellesen (i: Barrett 2016: 138ff).

Mens livsfilosofi og etik i faghæftet for kristendomskundskab fra 2009 og frem til i dag beskrives som det kompetenceområde, der kan integrere de øvrige områder (Børne- og undervisningsministeriet 2019: 27), så fylder fagfilosofi ikke meget i det danske fag. Det nævnes i det gældende faghæfte, at man kan anvende filosofiske samtaler i faget - $\mathrm{fx}$ i arbejdet med etik. Den fagfilosofiske tilgang adskiller sig i ovenstående opstilling fra den livsfilosofiske ved at anvende en tydelig metode for samtale samt i sit bagvedliggende menneskesyn og hele dannelsesmålet. I praksis kan man finde eksempler på filosofiske samtaler, som kan være umulige at kategorisere som det ene eller det andet, men den idealtypiske opstilling har til hensigt at gøre de studerende bevidste om og tydelige i deres formulerede målsætninger samt valg af metode og indhold, når de arbejder filosofisk med deres elever. 
De to sidste tilgange i skemaet er den komparative tilgang og den antropologiske tilgang. De trækker begge på den britiske religionsdidaktiske tradition og bygger på religionsvidenskaben. Den komparative undervisning - i den variant, som jeg har valgt at beskrive her - har komparative kategorier og typologi i sit fokus. Der er tale om kategorier/fænomener, som religionsvidenskaben har undersøgt komparativt. Ud fra disse synkrone analyser har religionsvidenskabere opstillet generaliserede teorier og typologier, som forskere - og elever - kan anvende til at analyse fx myter, ritualer og kosmologier. Når man arbejder ud fra denne version af den komparative tilgang, så behøver man således ikke at sammenligne noget, men der er tale om et bevidst valg af, hvordan man vil gå til sin kilde, hvilket sker på baggrund af typologier, teorier og metoder, der er udarbejdet i den komparative religionsforskning.

Den antropologiske tilgang skal ses i forlængelse af bl.a. Robert Jacksons kritik af den komparative undervisning i verdensreligioner. Hvor den komparative undervisning har som en del af sit mål at kunne sige noget generelt om religiøse kategorier, så vil den antropologiske undervisning interessere sig for individuelle fortolkninger og dermed den levede religion for at undgå generaliseringer og dannelse af stereotyper. Metoderne er feltarbejde i form af observation og interviews, men det betyder ikke, at eleverne behøver at bedrive dette feltarbejde. Ligesom med den komparative tilgang, så handler det om, hvilket syn på religion, der ligger til grund for undervisningen/undervisningsmaterialet, samt hvilket indhold og hvilke metoder eleven følgelig bliver bedt om at anvende. En antropologisk undervisning kan således være analyser af og refleksion over et interview, som eleverne får præsenteret i undervisningsmaterialet.

Ovenstående skema er tænkt som idealtypisk opstilling, der kan anvendes analyserende og refleksivt i udvikling af undervisning. Men det er også hensigten at typologien bliver udfordret. At kategorierne og beskrivelserne deraf bliver diskuteret, men ligeledes at fagdidaktikeren søger at finde nye og givende kombinationsmuligheder af for eksempel dannelsesmål og indholdsvalg.

\section{LitTERATUR}

Barrett, Toftgaard Barrett, Marlene Printz Jellesen, Bog Digernes Stokholm (red.) (2016): Bestand og bevagelse. Religionsundervisning og religionspaedagogik, Frederiksberg: Eksistensen.

Buchardt, Mette (red.) (2006): Religionsdidaktik, København: Gyldendal.

Buchardt, Mette (red.) (2016): Religionsdidaktik. Traditioner og tilgange, København: Hans Reitzels Forlag.

Børne- og undervisningsministeriet (2019): Kristendomskundskab. Faghaefte 2019 (https://emu.dk/sites/default/files/2020-09/Gsk_fagh\%C3\%A6fte_ Kristendomskundskab.pdf) 
Böwadt, Pia Rose (2007): Livets padagogik? En kritik af livsfilosofien og dens paedagogisering, København: Gyldendal.

Læremiddel.dk: Digitale laereplaner - kristendomskundskab: http://digitalelaereplaner.dk/fag/kristendomskundskab 